\title{
BMJ Global Health Polio: abandoning eradication would result in rapid resurgence of an ancient scourge
}

\author{
Roland Walter Sutter, Michel Jose Zaffran
}

To cite: Sutter RW, Zaffran MJ. Polio: abandoning eradication would result in rapid resurgence of an ancient scourge. BMJ Global Health 2019;4:e001877. doi:10.1136/ bmjgh-2019-001877

Handling editor Seye Abimbola

Received 30 July 2019 Accepted 30 July 2019

\section{SLinked}

- http://dx.doi.org/10.1136/ bmjgh-2019-001633

\section{Check for updates}

(C) Author(s) (or their employer(s)) 2019. Re-use permitted under CC BY-NC. No commercial re-use. See rights and permissions. Published by BMJ.

Polio Eradication Department, World Health Organization, Geneve, Switzerland

Correspondence to Professor Roland Walter Sutter; sutterr@who.int
In 1988, the World Health Assembly, the governing body of the $\mathrm{WHO}$, resolved to eradicate poliomyelitis by the year $2000 .{ }^{1}$ The resolution resulted in an unprecedented effort to combat one of the major sources of permanent disability. Of the three wild poliovirus serotypes, wild poliovirus type 2 was last isolated in 1999, serotype 3 was last detected in 2012 and only a single wild-type serotype, type 1 , is continuing to circulate and cause paralytic disease. $^{2}$ However, although much has been achieved, eradication remains elusive.

Four WHO Regions, including the Region of the Americas in 1994 (last indigenous virus in 1991), ${ }^{3}$ the Western Pacific Region in 2000 (last indigenous virus in 1997), ${ }^{4}$ the European Region in 2002 (last indigenous virus in 1998$)^{5}$ and the South East Asian Region in 2014 (last indigenous virus in 2011), ${ }^{6}$ have been certified by Regional Certification Commissions as free of the three wild poliovirus serotypes. This certification process has been robust, few importations of wild poliovirus into the European and Western Pacific Regions were documented and the ensuing outbreaks were rapidly and fully stopped. ${ }^{78}$ Two WHO Regions (the African Region and the Eastern Mediterranean Region (EMR)) have not yet achieved this milestone. The African Region is close to certification with the last isolation of wild poliovirus occurring in September 2016. Two countries in EMR (Afghanistan and Pakistan) remain endemic for wild poliovirus type $1 .^{2}$

The 'last inch' is indeed very difficult to achieve in the last two remaining countries. A number of new and old challenges stop the programme tantalising short of eradication. The major ones are access to the population because of conflict and the quality of campaign activities. The programme is increasingly affected by vaccine hesitancy and security. In this context, the move to a control

\section{Summary box}

In 1988, the World Health Assembly resolved to eradicate poliomyelitis by the year 2000 , resulting in an unprecedented effort to combat one of the major sources of permanent disability. Impressive progress has been achieved, however eradication remains elusive.

- Four of six WHO Regions have been certified as free of the three wild poliovirus serotypes-of the two remaining WHO Regions, the African Region is close to certification, but Afghanistan and Pakistan (in the Eastern Mediterranean Region) remain endemic for wild poliovirus type 1.

- The major challenges relate to access, conflict and the quality of campaign activities, and increasingly, vaccine hesitancy-in this context, the move to a control programme, rather than continuing efforts to achieve eradication, seems like a logical question to raise.

- But this is an unrealistic expectation; controlling the circulation of the polio virus is impossible, because there are many settings with low routine immunisation coverage - if we abandon eradication efforts, we would have to brace for high numbers of outbreaks and children with permanent disabilities.

- The global polio eradication objective is feasible, as has been demonstrated repeatedly, over very large geographic areas such as the entire Western hemisphere and the Indian subcontinent, and can be secured as the Region of the Americas has demonstrated since 1991.

- Ultimately, the world must decide whether the global good of polio eradication is worth achieving - and to move forward, ownership in the two remaining countries and continuous improvement of eradication efforts is of paramount importance to which the Global Polio Eradication Initiative remains committed.

programme, rather than continuing efforts to achieve eradication, seems like a logical question to raise.

The progress in the WHO polio-free Regions encouraged the preparation and implementation of a new endgame strategy ${ }^{9}$ that called for the withdrawal of Sabin type 2 from the 
trivalent oral poliovirus vaccine (tOPV) in 2016 (ie, 'the switch'), as a first step to an OPV-free world. Currently, efforts are ongoing to stop outbreaks in sub-Saharan and the Horn of Africa of circulating vaccine-derived poliovirus type 2 (cVDPV2), a virus that originates from the vaccine and was seeded from tOPV before the switch or monovalent type 2 OPV (mOPV2) use after the switch.

The Global Polio Eradication Initiative (GPEI) anticipated, based on modelling, ${ }^{1011}$ the occurrence of cVDPV2 outbreaks in the period following the switch. A global stockpile of $>500$ million doses of mOPV2 was contracted with two manufacturers. What the programme was less prepared for was that the outbreak control activities with mOPV2 could rapidly lead to the new emergence of cVDPV2, mainly due to poor campaign quality, and the spread of the cVDPV2 outbreak virus into adjacent geographies and across borders. For the control efforts to be successful, a high proportion of the targeted children needs to receive the vaccine.

Over the years, there have been repeated calls for converting the eradication initiative into a control programme. ${ }^{12}{ }^{13}$ Writing in BMJ Global Health, Razum et $a l^{14}$ suggest that we abandon the eradication target and replace it with 'sustained control'. For us, this is an unrealistic objective which was debated in previous communications. ${ }^{15}{ }^{16}$ Although 'sustained control' is not defined by the authors, we assume it to mean that we could maintain the accomplishments (few paralytic cases due to poliovirus) and divert the polio eradication funding to universal health coverage. In an epidemic-prone disease, such as poliomyelitis, we have experienced over and over during the past decades that control at low endemicity is impossible, primarily because of the large number of countries or areas or population groups with low routine immunisation coverage which leaves way to outbreaks. In an almost decade-old study in The Lancet, ${ }^{12}$ Thompson and Tebbens estimated that in a low very control scenario the incidence of paralytic poliomyelitis would reach approximately 200000 cases globally per year. Thus, if we abandon the eradication efforts, we would have to brace for high numbers of children with permanent disabilities.

It is hard to put a value on a child who walks today because poliovirus did not cause permanent paralysis. In a simple back of the envelope calculation, we use the number paralysis averted by the GPEI, approximately 18 million between 1988 and 2018, as numerator, and the external contributions during 1985-2018 used as denominator, approximately US $\$ 14.5$ billion. ${ }^{17}$ This puts a value of $\$ 800$ per paralysis averted. Although this is an underestimate since it does not capture the national contributions, it reflects the generous external contributions of the donor community. In addition, if we assume that the case fatality ratio among paralytic poliomyelitis cases is between 5\% and $10 \%$, between 900000 and 1800000 infants are alive today because of the eradication efforts. Would these accomplishments be worth preserving for the future?
The GPEI is spearheaded by six partners (Rotary International, Gavi (the Vaccine Alliance), the US Centers for Disease Control and Prevention, the Bill and Melinda Gates Foundation, UNICEF and WHO), supported by multilateral and bilateral health and development aid organisations, private industry and the governments of the affected countries. Polio eradication remains one of the largest public-private sector collaborations to achieve a public health goal. Despite substantial challenges along the eradication pathway, these partners remain committed to see eradication to the ultimate conclusion.

The global programme has mastered many challenges, including a ban on polio vaccination in Northern Nigeria in $2004,{ }^{18}$ the low immunogenicity of polio vaccines in Northern India, ${ }^{19}$ the inaccessibility of most of Borno State, Nigeria, ${ }^{20}$ and the targeting of polio workers for assassination in Pakistan, ${ }^{21}$ to mention but a few. Much has been overcome, but much more needs to be done.

Thus, Razum et $a l^{14}$ are correct when they write 'There is one strategy, however, that the world should not be content with: namely more of the same.' More of the same has brought the polio eradication effort very close to the finish line, but indeed the last two countries must assume much greater responsibility for the programme, coordinate their efforts and make eradication their national priority.

The cVDPV2 outbreaks in sub-Saharan Africa require both quality improvements in field activities and a technological solution. The current mOPV2 relying on Sabin strains is inherently genetically instable and its use will always be associated with the risk of new emergences of cVDPV2. This problem was recognised by the GPEI almost a decade ago, and an ambitious research agenda resulted in the first in human use of a genetically more stable new type 2 OPV (nOPV2). ${ }^{22}$ Subsequent clinical trials are under way, and if the vaccine performs as expected, in 12-18 months the large-scale use of nOPV2 will demonstrate whether we can retire the Sabin type 2 strains to history.

Eradication is difficult, and the GPEI is the first to acknowledge the remaining challenges. New commitments, efforts and strategies are indeed needed. The global community has also realised that the polio eradication programme cannot be the panacea for solving ethnic strife, civil war or inaccessibility for delivering the polio vaccines and conduct surveillance. The problems require country leadership and ownership.

We agree with Razum et $a l^{14}$ that while there have been many achievements to date, many problems remain that continue to delay the initiative reaching the eradication target. What we do not agree with is the proposed solution. The GPEI made a promise to ensure no child will ever be paralysed by the polioviruses. The global polio eradication objective is feasible, as has been demonstrated repeatedly, over very large geographic areas such as the entire Western hemisphere and the Indian subcontinent, and can be secured as the Region of the Americas 
has demonstrated since 1991 (almost 28 years without paralysis caused by wild polioviruses). ${ }^{3}$

To move forward, country ownership in the two remaining countries is of paramount importance. We also need to critically review the eradication strategies and be bold where necessary. Ultimately, the world must decide whether the global good of polio eradication is worth achieving. For us in the programme, we would like to stay with a disease "that future generations know by history only... ${ }^{23}$ and not one that future generations will blame us for giving up so close to the finishing line and failing to wipe out once and for all.

Funding The authors have not declared a specific grant for this research from any funding agency in the public, commercial or not-for-profit sectors.

Competing interests None declared.

Patient consent for publication Not required.

Provenance and peer review Commissioned; internally peer reviewed.

Data availability statement № additional data are available.

Open access This is an open access article distributed in accordance with the Creative Commons Attribution Non Commercial (CC BY-NC 4.0) license, which permits others to distribute, remix, adapt, build upon this work non-commercially, and license their derivative works on different terms, provided the original work is properly cited, appropriate credit is given, any changes made indicated, and the use is non-commercial. See: http://creativecommons.org/licenses/by-nc/4.0/.

\section{REFERENCES}

1. World Health Assembly. Global eradication of poliomyelitis by the year 2000: resolution 41.28. Geneva, Switzerland: World Health Organization, 1988.

2. Greene SA, Ahmed J, Datta SD, et al. Progress toward polio eradication - worldwide, january 2017-march 2019. MMWR Morb Mortal Wkly Rep 2019;68:458-62.

3. Robbins FC, de Quadros CA. Certification of the eradication of Indigenous transmission of wild poliovirus in the Americas. J Infect Dis 1997;175(Suppl 1):S281-S285.

4. Centers for Disease Control and Prevention (CDC). Certification of poliomyelitis eradication-Western Pacific region, October 2000. MMWR Morb Mortal Wkly Rep 2001;50:1-3.

5. Vilayleck MS. The WHO European region declared free of polio. Euro Surveill 2002;7:76-7.
6. Bahl S, Kumar R, Menabde N, et al. Polio-free certification and lessons learned--South-East Asia region, March 2014. MMWR Morb Mortal Wkly Rep 2014;63:941-6.

7. Yakovenko ML, Gmyl AP, Ivanova OE, et al. The 2010 outbreak of poliomyelitis in Tajikistan: epidemiology and lessons learnt. Euro Surveill 2014;19.

8. Wang H-B, Yu W-Z, Wang X-Q, et al. An outbreak following importation of wild poliovirus in Xinjiang Uyghur autonomous region, China, 2011. BMC Infect Dis 2015;15:34.

9. Global Polio Eradication Initiative. Polio Eradication \& Endgame Strategic Plan 2013-2018. Geneva, Switzerland: World Health Organization, 2013.

10. Thompson KM, Tebbens RJD. Current polio global eradication and control policy options: perspectives from modeling and prerequisites for oral poliovirus vaccine cessation. Expert Rev Vaccines 2012;11:449-59.

11. Duintjer Tebbens RJ, Thompson KM. Managing the risk of circulating vaccine-derived poliovirus during the endgame: oral poliovirus vaccine needs. BMC Infect Dis 2015;15:390.

12. Thompson KM, Tebbens RJD. Eradication versus control for poliomyelitis: an economic analysis. The Lancet 2007;369:1363-71.

13. Duintjer Tebbens RJ, Pallansch MA, Cochi SL, et al. Economic analysis of the global polio eradication initiative. Vaccine 2010;29:334-43.

14. Razum $O$, Sridhar D, Jahn A, et al. Polio: from eradication to systematic, sustained control. BMJ Global Health 2019;4:e001633.

15. Arita I, Francis DP. Safe landing for global polio eradication: a perspective. Vaccine 2011;29:8827-34

16. Arita I, Nakane M, Fenner F. Public health. is polio eradication realistic? Science 2006;312:852-4.

17. Rotary International. International polio plus Committee polio plus facts and figures June 2018. Available: https://www.endpolio.org/ sites/default/files/facts_and_figures_june_2018_en-.pdf [Accessed 21 May 2019].

18. Samba E, Nkrumah F, Leke R. Getting polio eradication back on track in Nigeria. N Engl J Med 2004;350:645-6.

19. Grassly NC, Fraser C, Wenger J, et al. New strategies for the elimination of polio from India. Science 2006;314:1150-3.

20. Higgins J, Adamu U, Adewara K, et al. Finding inhabited settlements and tracking vaccination progress: the application of satellite imagery analysis to guide the immunization response to confirmation of previously-undetected, ongoing endemic wild poliovirus transmission in Borno state, Nigeria. Int J Health Geogr 2019;18:11.

21. Polio worker shot dead in Pakistan, over 100 killed since December 2012. Hindustan times 27 July 2017. Available: https://www. hindustantimes.com/world-news/polio-worker-shot-dead-inpakistan-over-100-killed-since-december-2012/story-7nt0hXxatmuG NwrFe2wCsJ.html [Accessed 10 July 2019].

22. Van Damme P, De Coster I, Bandyopadhyay AS, et al. The safety and immunogenicity of two novel live attenuated monovalent (serotype 2) oral poliovirus vaccines in healthy adults: a double-blind, singlecentre phase 1 study. Lancet 2019;394:S0140-6736(19)31279-6

23. Foege WH. A world without polio. 'Future generations will know by history only...'. JAMA 1993;270:1859-60. 